\title{
FOXC1 Gene
}

National Cancer Institute

\section{Source}

National Cancer Institute. FOXC1 Gene. NCI Thesaurus. Code C131542.

This gene plays a role in the regulation of both embryonic and ocular development. 